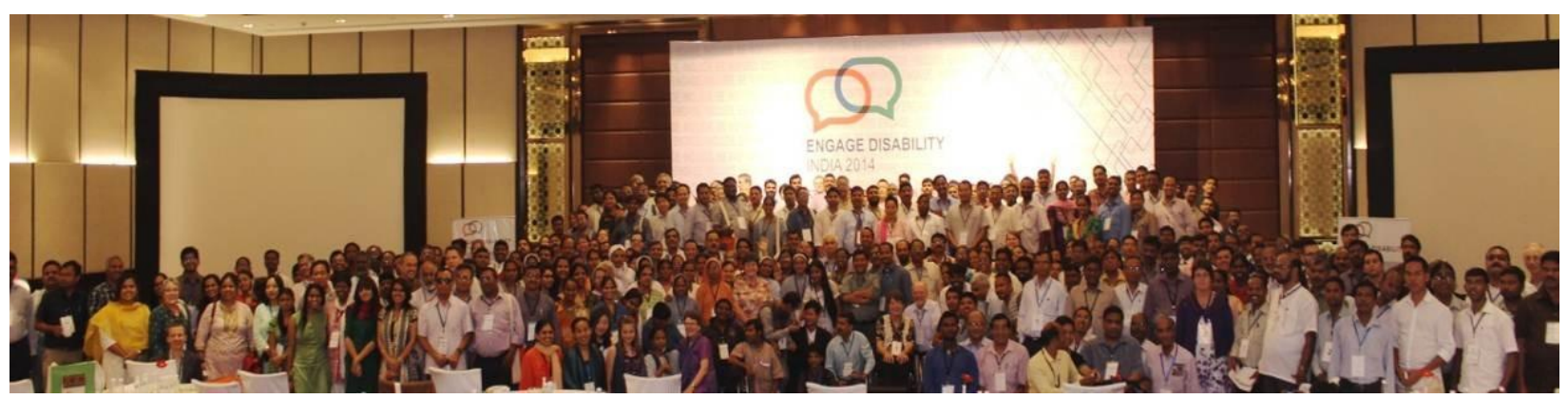

\title{
Engage Disability Conference
}

\author{
Sylvia Naomi James ${ }^{a}$, Nathan Grills ${ }^{b}$ and Jubin Varghese ${ }^{c}$ \\ ${ }^{a}$ Conference Coordinator, Engage Disability, India \\ ${ }^{\mathrm{b}}$ Public Health Physician, Nossal Institute for Global Health, University of Melbourne. Consultant Emmanuel \\ Health Association (EHA), Australia \\ ${ }^{\mathrm{c}}$ Deputy Director of Community Health and Disability Program Manager, Emmanuel Health Association, India
}

The Engage Disability conference was held at Crowne Plaza, Rohini, New Delhi from 25th to $27^{\text {th }}$ September 2014. This conference was designed to inspire and strengthen our efforts to see people, regardless of ability, engaging with our faith communities. We had senior representation from most major Christian health organizations and various churches in India including WVI, CHAI, CBM, NCCI, TLM, EHA, CMC Vellore, Compassion, Tear fund, and JAF, Equip India, bible colleges, and various programs working on disability. Over 400 people participated with great enthusiasm, and the delegates included 210 pastors/ theologians/ church leaders and 154 members from various NGOs working in CBR and other disability programs.

The conference opened with the leaders praying for the conference and then signing the conference banner with a hand print. All delegates later signed the same banner, and the final conference declaration was signed over the top of this kaleidoscope of colored hand prints. This was a beautiful representation of all Christians giving a hand to work towards the declaration: to see those with disability accompanied, loved, and included in the body of Christ!

\section{Sessions}

Sessions were divided into 4 logical sections that progressed from looking up at God, into our church, around us at our families and out to the world:

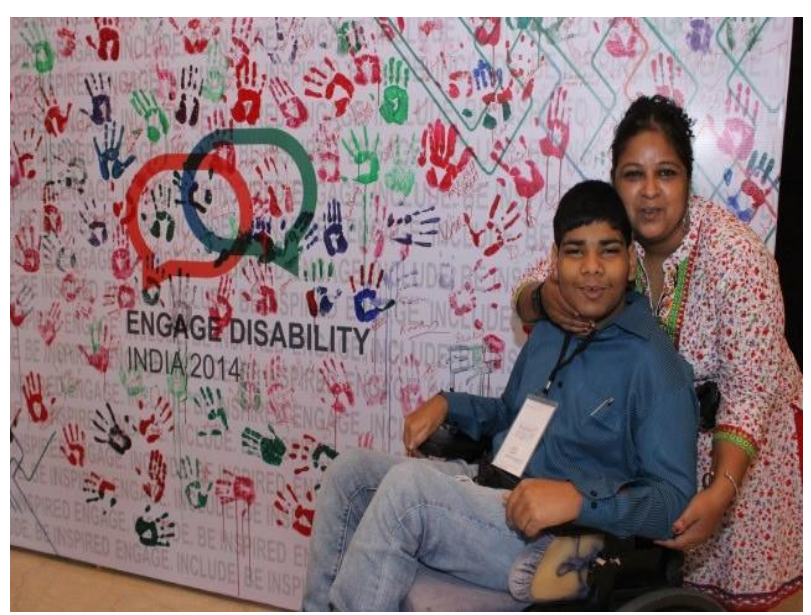

May 2015. Christian Journal for Global Health, 2(1): 75-79. 


\section{Disability and theology (looking up at God)}

A number of superb speakers covered what Jesus, the Church, and the Bible says about disability. Topics included "How can the church be more inclusive" by Kenneth Campbell and some excellent overviews by Prince David (Tearfund), Rev. Christopher Raj Kumar (head of the NCCI disability movement), Dr. Father Tomi Thomas (CHAI), and Dr. Ben
Rhodes. All gave a compelling framework for Christians to love and include those with different abilities. Rev. L.T. Jeyachandran, RZIM, who himself was challenged in preparing these studies, explained how being created "in the image of God" meant that we should take pride in our ability and disabilities as they reflect God.
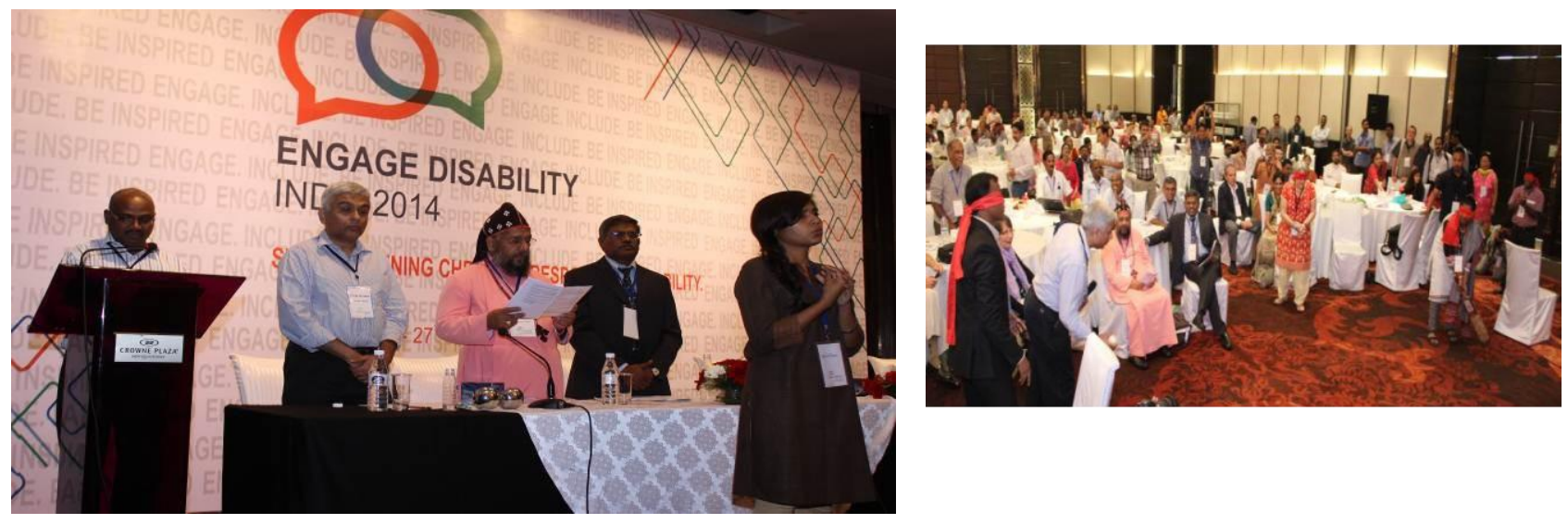

\section{The inclusive church (looking inwards)}

This session covered how bible colleges, pastors, and church members can work together so that people with disability are included in all aspects of church life. Brian McKinney spoke about the need for social ramps, referring to the church examining social and attitudinal barriers and not just physical barriers. Dr Ben Rhodes introduced the Beyond Suffering course that gives a Christian approach to disability. Jayakumar Christian (WVI) challenged the church to transform India by its love for the most marginalized. Pastors shared their stories about inclusion. One church in Nepal had 50 people who had mobility issues, and another church had sign language interpretation at every service and special services reaching out to the deaf. There were also stories of congregations in Mumbai where churches were competing to be the most inclusive church. Inclusion was not seen as a burden but something to be cherished and aspire to. A recurrent theme was that this was not the job of a few inspired pastors, although we heard from many, but the role of every Christian in India! We are the church!

\section{Disability and families}

In this session, the focus was on the lived reality (looking around) of parents, siblings, and caregivers. There were many heartwrenching stories of exclusion, but an equal number of stories of families being welcomed and helped by the Christian community in India. The plenary session had a powerful testimony from Pastor Sanjeev who explained how his church had come to accept and now even celebrate the uniqueness of his child who has autism. Jessica Paulraj spoke about how their adoption of a child with severe disabilities had transformed their family and impacted the community around them who asked "why do 
they love that child?" There can only be one answer for the Paulrajs. There were not many dry eyes left after these keynotes. A session on Caring for Families with Disabilities, chaired by Mr. George Abraham, Dr. Nathan Grills, Dr.
Judy, Lenny Vasanthan, and Raj Kumar, spoke about the simple things like buddies and random acts of kindness that Christians can do to care for families.

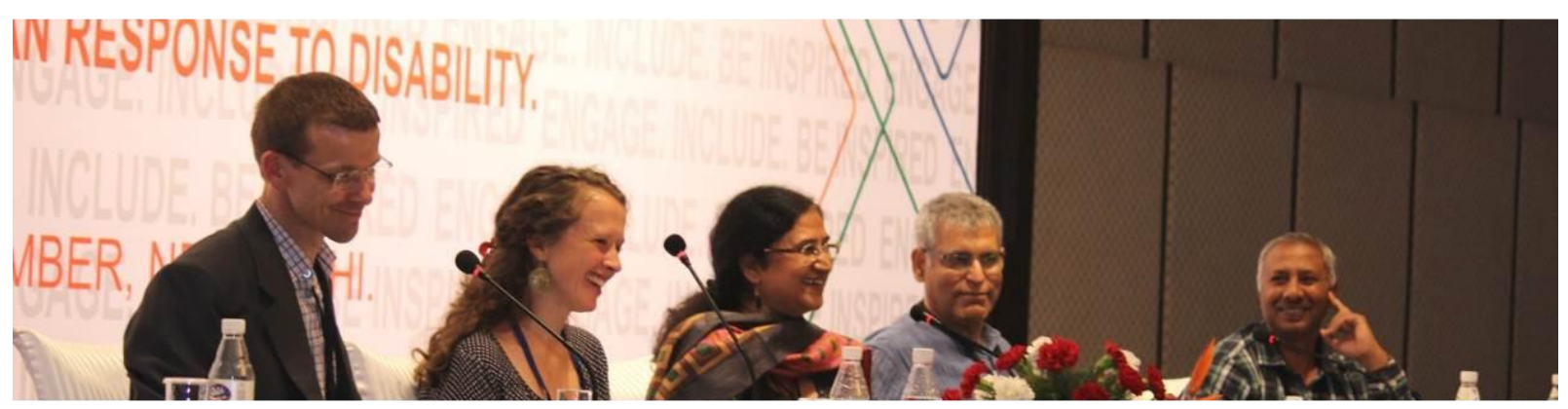

Faith and disability inclusive development (looking out to the world)

The final day was opened by Dr. Dave McComiskey, the international head of CBM, who delivered a challenging message on how including the most marginalized had transformed communities and made society a better place. We heard challenges from Mr. Brian McKinney, Geeta Mondal, Dr. Charles Kingery (ProVISION Asia), Ms. Pramila Balasundaram • (Samadhan), Melody Murray (JOYN), and • others about how we can reach out to India through disability inclusive health, education, • and vocational training. Many well-known Christians gave their greetings and well wishes including Joni Eareckson Tada (Joni and Friends), Nick Vujicic (Beyond limits), Ravi ${ }^{\bullet}$ Subbaiah (NMTV), Bear Grylls, and Mr. George Abraham (founder of Blind Cricket). George gave us a live onstage demonstration of blind cricket.

The breadth of the Christian community • came together to sign a petition to the govern- ment demanding they fully enshrine the UN Convention on the Rights of the People With Disability into Indian law. Two well-known disability advocates are arranging to present this to the Prime Minister of India, Mr. Narendra Modi.

\section{Regional Networking (Facilitated by the Community Health Global Network)}

The conference had intentional networking sessions where people from different regions were grouped together, shared ideas, appointed regional facilitators, and planned a way forward at the local level. This resulted in 13 regional sub groups:

NEPAL

NORTH 1 (Uttarakhand)

NORTH 2 (Jammu \& Kashmir, Himachal Pradesh, Punjab, Haryana, Chandigarh)

NORTH EAST (Assam, Arunachal, Sikkim, Nagaland, Meghalaya, Manipur, Mizoram, Tripura)

DELHI, Uttar Pradesh

CENTRAL Madhya Pradesh, Chhattisgarh

EAST 1 (Bihar, Jharkhand)

EAST 2 (West Bengal, Odisha)

WEST (Rajasthan, Gujarat, Goa, Maharashtra, Daman \& Diu, Dadra, Nagar Haveli)

- SOUTH 1 (Tamil Nadu, Kerala)

SOUTH 2 (Telangana / Hyderabad)

SOUTH 3 (Karnataka, Lakshadweep, Andaman \& Nicobar, Pondicherry, Andhra Pradesh)

These regional networks have the contact details of their members and will be facilitated to create a platform for unity, prayer, and synergy. We are asking each region to steward the momentum in the coming months by engaging 
their regional brothers and sisters. Many regions have already had meetings and corre- spondence.

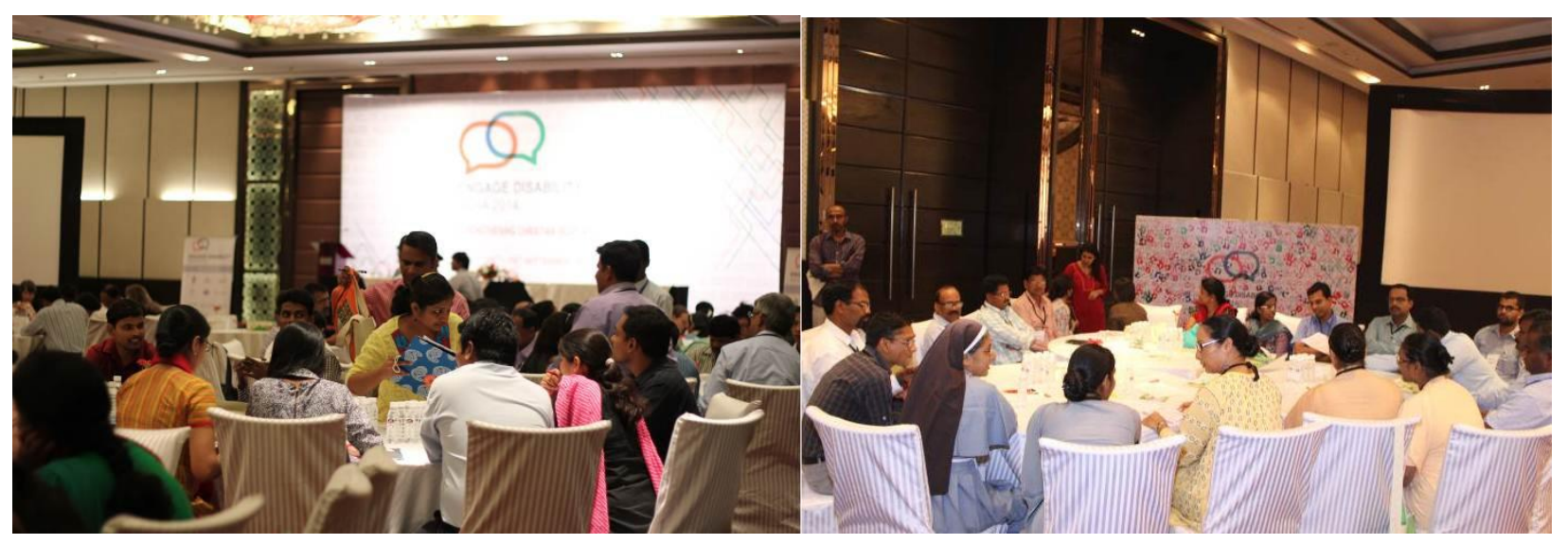

\section{The Way Forward}

The conference was concluded by challenging words from Dr. Sara Varughese (Director of CBM) and Rev. Dr. Abraham Mar Paulose, Bishop, Marthoma Church. Dr. Santhosh Mathew (Director of EHA) presented "Where to from here." "This cannot just be a conference but must be a movement!" He outlined how the strategic advisory committee and key conference delegates had met during the evenings to collate ideas and create a vision for the way forward. To see this happen, the following were outlined:

Focus on supporting the regional hubs (NCCI to lead)

- A Communication Hub (World Vision to lead) was created to facilitate intra-regional, interregional, and international communications

- A Resources Hub (CHAI to lead) to compile

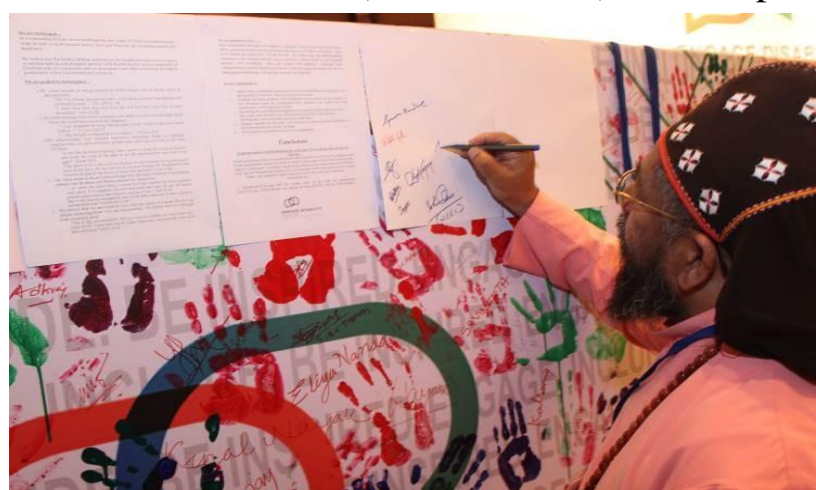

and create different tools to help the Christian community move towards inclusive Christian communities

- A Coordinating hub that supports and facilitates the functioning of the other hubs

Below are 4 action steps we would like each region to take in the next four weeks, during which members of Engage Disability Partners will be in further communication:

1. Kindly work towards scheduling the 1 st gathering for the purpose of prayer, growing friendships, and deciding movement for the next quarter.

2. Email the facilitators from your region to arrange meeting/cooperation and plan future activities.

3. Email everyone in your region to update them on progress and arrange a forum for discussions.

4. Be in prayer.

Finally, a declaration that had been drafted by conference delegates was signed by leaders of the partner organizations:

... We, the body of Christ, affirm that everyone, including persons with disabilities are created by God, in the image of the triune God; and therefore have the potential to be full and active members of the Church, 
communities and the society at large. The Mission of God is an imperative; and therefore, the mission along with and for the disabled is a participatory mission to accompany the persons with disabilities so as to ensure their full contribution to our churches ... (extract from declaration)

We wish to thank the conference organizing team (Dr. Charles, M s. Meena, Ms. Sylvia
James, Ms. Jubin, Rev. Ben Richards, Dr. Nathan Grills), our MC Mr. KA Jayakumar, the volunteers, the churches, and the generous conference partners (below) for making this dream a reality. Most of all, we want to thank and praise God for bringing this together for His Glory - a glory that we see clearly displayed through the inclusive Christian community.
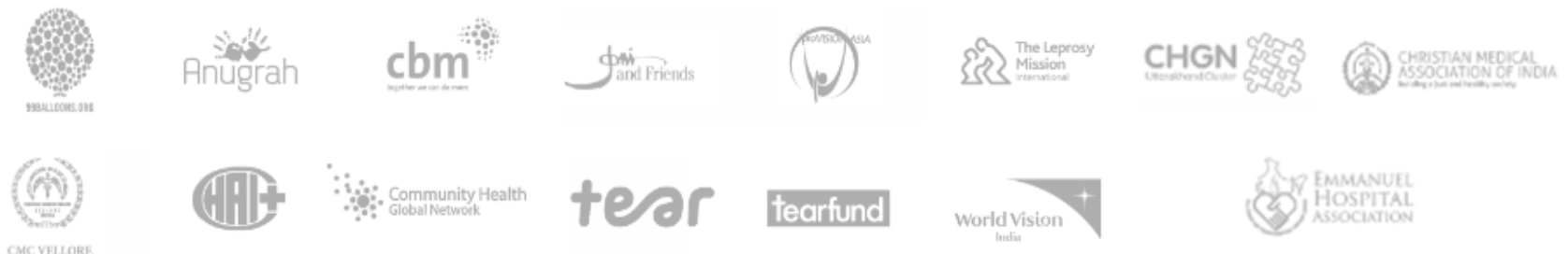

PMC VELLORE
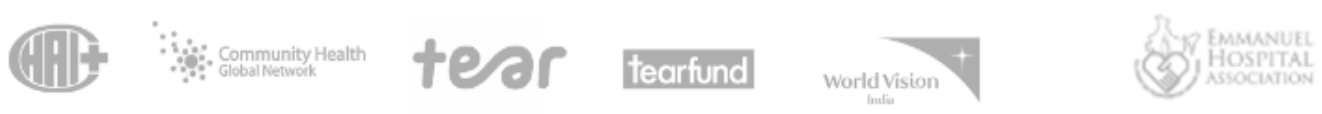

Glossary:

WVI: World Vision India, CHAI: Catholic Health Association of India, NCCI: National Council of Churches in India, TLM: The Leprosy Mission, EHA : Emmanuel Hospital Association, CMC Vellore: Christian Medical College, JAF: Joni and Friends, RZIM: Ravi Zacharias International Ministries, CHGN: Community Health Global Network, CMAI: Christian Medical Association of India.

Competing Interests: None declared.

Correspondence: Sylvia Naomi James, Engage Disability Conference, sylvia.engagedisability@gmail.com

Cite this article as: James SN, Grills N, Varghese J. Engage Disability Conference Report. Christian Journal for Global Health (April 2014), 2(1): 75-79.

(C) James SN, Grills N, Varghese J. This is an open-access article distributed under the terms of the Creative Commons Attribution License, which permits unrestricted use, distribution, and reproduction in any medium, provided the original author and source are properly cited. To view a copy of the license, visit http://creativecommons.org/licenses/by/3.0/

$$
\text { wWw.cjgh.org }
$$

